\title{
PROBATION OFFICERS AND THE EXPERIENCE OF JUVENILE OFFENDERS IN THE JUVENILE SYSTEM
}

\section{Taufik Mohammad ${ }^{*}$ and Azlinda Azman}

School of Social Sciences, Universiti Sains Malaysia, Pulau Pinang, MALAYSIA "Corresponding author: fik@usm.my

Published online: 28 September 2018

To cite this article: Taufik Mohammad and Azlinda Azman. 2018. Probation officers and the experience of juvenile offenders in the juvenile system. Kajian Malaysia 36(2): 69-88. https://doi. org $/ 10.21315 / \mathrm{km} 2018.36 .2 .4$

To link to this article: https://doi.org/10.21315/km2018.36.2.4

\begin{abstract}
Probation officers are among the individuals who come in closest contact with juvenile offenders in Malaysia. They have extensive responsibilities in the juvenile justice, such as interviewing the juvenile offenders about their social system, writing a probation report for the court, and making recommendations based on their observations. This makes them reliable figures for ascertaining what is happening in the juvenile system. Based on this, this article argues that it is pivotal to study the perceptions of the probation officers regarding the juvenile experience to understand the effectiveness of the system. In this mixed method study, 12 probation officers from 6 states in Malaysia were interviewed. The close-ended items required them to rate each component of the questionnaire, which are related to aspects of the preparation of offenders for entry into the system, their participation inside the system, and their outcomes. The participants' ratings indicated higher-than-average satisfaction. However, the qualitative data showed a mixed response, with respondents expressing more scepticism about the system and often focusing on external factors. Additionally, the probation officers discussed the importance of modules for the juvenile offenders' benefit upon release. The responses from the probation officers shed light on how the experiences of the juvenile offenders can be improved through a three-layer plan that includes the process of preparation, detention, and release.
\end{abstract}

Keywords: Probation officers, juvenile offenders, juvenile justice 


\section{INTRODUCTION}

Probation officers (pegawai akhlak) in Malaysia are among the most important figures in a juvenile offender's experience. Before the roles of probation officers can be discussed, it is important to consider the context of how institutionalisation started in the Malaysian criminal justice system. This is a pivotal discussion because many responsibilities of a probation officer can be related to institutionalising the juvenile offenders. Consequently, understanding the relationship between juvenile offenders and probation officers in Malaysia requires understanding the history of institutionalisation in the country.

In Malaysia, an objective of the criminal justice system is to both punish and rehabilitate offenders (Mohd Al Adib and Nooraziah, 2009). However, despite the emphasis on rehabilitation that has a non-custodial element to it, Malaysia's approach toward dealing with children in conflict with the law has been approximately the same since it was introduced in 1947 (Ministry of Women, Family and Community Development and UNICEF Malaysia, 2013), continuing a system that often resorts to institutionalising the juvenile offenders.

One of the purposes of institutionalisation in Malaysia is to prepare the juvenile offenders for their return in the community (Jaafar, 1978). This preparation involves the development of the juvenile offenders' character and social responsibility. In the context of juvenile delinquency in Malaysia, there are three methods of institutionalisation of juvenile offenders (as stipulated in Section 91 of Child Act 2001): juvenile probation hostels, probation schools, and Henry Gurney schools (a type of detention school operated by the Malaysian Prison Department).

The Malaysian Child Act 2001 has provided a detailed explanation of the function of these three types of institutionalisations. Probation hostels house children of not less than 10 years old in detention for a probationary period not exceeding 12 months. On the other hand, probation schools are schools approved by the court to house juvenile offenders for up to three years. For children not less than 14 years old who commit major crimes that require detention, Henry Gurney schools often become the option of choice. Unlike the children housed in probation hostels and schools, where the maximum age is up to 18 years old, children placed in Henry Gurney schools can be detained up to 21 years of age.

\section{INSTITUTIONALISATION OF JUVENILE OFFENDERS}

Many studies have looked into the differences between institutionalisation and its counterpart - deinstitutionalisation - in rehabilitating offenders (Lipsey, Wilson and Cothern, 2000). Although an increasing number of studies have highlighted the effectiveness of the approach of deinstitutionalisation (Chung and Steinberg, 
2006; Galbavy, 2003), institutionalisation is still a common practice in many countries, including Malaysia. This article does not aim to recommend the abolishment of institutionalisation, given how it is a major part in the juvenile system in Malaysia. However, this article, through understanding the experiences of the juvenile offenders through the eyes of the probation officers, would like to seek to understand how it can be improved. Institutionalisation, after all, can still be effective, depending on the way the institutionalised programme is operated; for instance, research has recommended institutionalisation as a means to address the social skills and the cognitive-behavioural well-being of the offenders (Lipsey, Wilson and Cothern, 2000). When institutes use effective approaches, effective development of offenders' social responsibility and character can be achieved through institutionalisation.

Historically, formal scrutiny of institutionalisation started with questions raised about the efficacy of retribution and punitiveness in reducing the crime rates and costs (Heslop, 1991). These critiques fed into the abolitionist movement, which argued that the conventional justice system, driven by retribution and punitiveness, should no longer be perceived as a legitimate way in addressing crimes (Wemmers, 2009). The result of this movement was increasing support among advocates and scholars for "diversion", a non-custodial approach that diverts offenders away from the judiciary system and institutionalisation (McLaughlin and Muncie, 2013).

As previously mentioned, and despite the sea-change in expert thought, the criminal justice system in Malaysia has been approximately the same since 1947 (Ministry of Women, Family and Community Development and UNICEF Malaysia, 2013), with the system remaining punitive in most respects (Nasimah, 2010). Some have argued that institutionalisation should be the option of last resort (Ministry of Women, Family and Community Development and UNICEF Malaysia, 2013; Suruhanjaya Hak Asasi Manusia Malaysia [SUHAKAM], 2008). However, according to the Social Welfare Department of Malaysia, 4,669 children were "in conflict with the law" and 1,228 were institutionalised in probation hostels or schools. While the exact number may be obscured - those who are institutionalised may include those who were not in conflict with the law, but categorised as "beyond control" by their guardians - this high number of institutionalised children suggests a criminal justice system dependent on the practice of institutionalisation.

This dependency on institutionalisation becomes further manifest when considering the nexus between institutionalisation and punitiveness. Previous research has argued that institutionalisation is both a correlate and a cause of punitiveness within criminal justice systems (Siegel and Welsh, 2016). After all, being isolated from society is - whether intended to be or not - quite punitive. This adds further urgency to assessing the experience of juvenile offenders inside of institutions. With that, we turn to the perceptions of probation officers - "first responders" who are well-positioned to illuminate the subject. 


\section{THE PROBATION OFFICERS}

It is hard to overemphasise the role of probation officers in the many aspects of offender rehabilitation. In their 2005 study, Paparozzi and Gendreau found that the orientation procedures that probation officers use in their practice affect the recidivism of offenders (Paparozzi and Gendreau, 2005). Self-reporting by probation officers also indicates that they view their relationship with offenders as one of the elements that brings meaning to their work (Worrall and Mawby, 2014). Probation officers also indicate that they see their relationships with offenders as key to providing rehabilitative services (Burnett and McNeill, 2005).

This arguably makes probation officers the closest "eyes and ears" to what works in the juvenile justice system. A general rule of policy formulation is that the policies have to be based on the perspective of the people affected by the policies (Dorey, 2005). As probation officers' voice in "what works" should be deemed central to evaluating the function and efficacy of the juvenile justice system (Annison, Eadie and Knight, 2008), understanding their feedback can help policymakers to formulate better juvenile policies.

In Malaysia, probation officers have an early and prominent role in juvenile justice cases. They enter juvenile cases when appointed to make probation reports for the juvenile offenders after being referred to by the police. Per Section 10 of the Child Act 2001, probation officers are social welfare officers, appointed work under court supervision in the Social Welfare Department of Malaysia. Among their first tasks are to interview the offenders and write a probation report that will be used by the court to make a decision on how to deal with the juvenile offenders. The task is among the eight orders stipulated in Section 91 of the Child Act 2001, reflecting the influential role the report has in a juvenile offender's life. The way probation officers assess juvenile offenders, and the relationship they develop with them, shape their perspective towards the process of juvenile rehabilitation - and, consequently, can shape the juvenile's experiences, as well.

\section{AIM OF THE STUDY}

In sum, probation officers are among the closest contacts that juvenile offenders have throughout the criminal process. Affirming the arguments proffered by Dorey (2005) and Annison, Eadie and Knight (2008), we place great emphasis on the role of probation officers in both shaping and perceiving juvenile justice systems. Accordingly, this study seeks to better understand the perceptions and beliefs of these "first responders," in service of moving toward a more effective and evidencebased juvenile justice system. 


\section{METHODS}

\section{Sample}

Our sample comprises probation officers assigned in the Child Unit of the Social Welfare Department of Malaysia at the time of study. The current assignment as a probation officer was an important criterion, as probation officers who are unassigned will not have current experience within the Child Unit. This was the only inclusion criterion used to recruit the respondents. Interviewing those who were already assigned ensured that the probation officers had current experience with the issues in this study. The researcher faced difficulties in recruiting respondents among the probation officers because of their hesitance to be interviewed. In the end, a total of 12 probation officers from six states (which were Johor, Kedah, Negeri Sembilan, Perak, Pulau Pinang, and Selangor) were recruited. All interviews were conducted by telephone.

\section{Material of the Study}

This study employed a mixed approach, combining both close- and open-ended items for the purpose of triangulation. The questionnaire was based on Mutter et al. (2008) questionnaire for young offenders, asking for their views and feedback on Family Group Conferences (FGC). The original questionnaire included three main elements: (1) processes of preparation to FGC; (2) processes of participation in FGC; and (3) outcomes of the participation. The study revised the original questionnaire so the key elements can be applied in the setting of the current study - the processes of the juvenile justice system in Malaysia. After a process of adjustment, the altered questionnaire assessed the probation officers' perceptions of the following:

1. The processes of preparing the child offenders into detention centres and probation schools, including the interviewing of offenders and preparation of probation reports (one open-ended and one close-ended item)

(a) How satisfied are you with the current processes for preparing the child offender into the system? (rated with a Likert 5-point scale where "1" indicates "least satisfied" and "5" indicates "most satisfied")

(b) Why did you rate that way? (open-ended) 
2. The rehabilitation of the child offenders by the institution's offered programmes (one open-ended and two close-ended items)

(a) How effective are the detention centre and probation schools in rehabilitating juvenile offenders? (rated with a Likert 5-point scale)

(b) Why did you rate that way? (open-ended)

3. The outcomes of juvenile offenders being housed inside the institution

(a) How much do you think that the juvenile offenders can change upon release? (rated with a Likert 5-point scale)

(b) Why did you rate that way? (open-ended)

4. An additional item, querying probation officers for suggestions of new initiatives that might improve the rehabilitation of juvenile offenders

As discussed, probation officers that work under the Social Welfare Department of Malaysia are appointed with the responsibility to interview and build probation reports that will impact the outcome of the trial process for juvenile offenders. Therefore, their involvement in the juvenile offenders' lives is pivotal in the pre-trial and trial stage of the criminal process (Items 1 and 2). However, their perspectives on the lives of the juvenile offenders' post-trial will also be integrated in the interview (Item 3 ) to form a comprehensive understanding of their perspectives.

\section{RESULTS AND ANALYSIS}

The following analysis will summarise the scores given by the probation officers for each item and their responses together with their explainations. Thematic analysis (Braun and Clarke, 2006) was used to analyse the emerging themes from the responses to the open-ended items. Note that the responses given for the openended items may not be reflective of the scores given for the close-ended items. Probation officers may give a high score, indicating a positive perception on a particular item, but they might respond differently in the open-ended section. This discrepancy will be discussed in a later chapter. 


\section{Question 1: The Processes of Preparing Child Offenders into Detention Centres and Probation Schools, Including Interviews and Preparation of the Probation Report}

For question one, all scores given were 3,4 , and 5 . The most frequent score given by the probation officers to this item is $4(\mathrm{n}=8)$. The mean for the score given to this item is 3.83 , higher than the average cut-off point (2.5). At face value, the sample showed a generally positive perception towards the effectiveness and efficiency of the process of preparing child offenders into the system.

However, the qualitative analysis indicated a mixed response from the sample. Firstly, there was only one respondent whose qualitative response matched his rating of "4" (Respondent 3). The respondent was satisfied with the current way of preparing the child offenders. He simply said, "Sebab benda ni bergantung kepada situasi semasa. Tapi sekarang dah bagus. (Because this depends on the current situation. But now it is already good)."

For the other responses, despite the scores that signified their positive perception, the probation officers made several critical remarks. The first theme that is observed is the amount of time the probation officers had to take in order to interview and prepare the probation report (Respondents 1, 5, 6, 7, 10, and 11). Respondent 1 said that, "Saya tak jumpa kerap sangat untuk interview budakbudak tu. Penilaian tu singkat sebab tempoh yang diberikan tu terhad. (I do not see the kids that often. The assessment is short because the time given is limited)." Respondent 5 was sceptical, "Bagi sayalah, tak perlu bagi syor kepada mahkamah. Sebab tempoh untuk siasat kes tu terhad. Kalau buat apa-apa usulan pun, rasanya tak tepat. (For me, no need to make any recommendations to the court. Because the time to investigate the case is limited. If I make any proposal, I do not think it is accurate)." Respondents 6 and 10 repeated the same point.

Continuing on the theme of inadequate time, Respondent 11 responded, "Masa terhad dan tak tahu kisah sebenar. Macam cerita budak lain, polis lain. Kadang-kadang polis nak senang kerja. SOP kerja bagus, boleh kerja dan tak membebankan. Kadang-kadang ada short notice so tak ada masa. (The time is limited and we do not know the real story. The kids have a different story and the police too. Sometimes the police just want it easy. The SOP (Standard Operating Procedure) is good, it works and does not burden. Sometimes, there is a short notice so there is no time)." Respondent 12 remarked that multiple interviews would provide better outcomes, remarking, "Kalau boleh interview lebih sekali dan interview secara sendiri dengan kanak-kanak untuk bina kepercayaan. (If possible, the interviews should be conducted more than once and done individually with the kids to build trust)." 
A second common theme was the importance of strong networks with other agencies involved in the process (Respondents 2, 8, and 9). Respondent 2 said, "Saya rasa kalau ada kerjasama yang bagus dan tangkas dari agensi lain lagi bagus. Sebab kami tak boleh bekerja seorang-seorang, mesti perlu bantuan agensi lain. (I think if there is a good and efficient cooperation with other agencies, it would be better. Because we cannot work alone, we need help from other agencies)." Respondent 8 had a similar response. Respondent 9 posited somewhat different concerns, stating, "Sebab ada kelemahan dari pihak keluarga untuk memantau. Kena ada peranan tapi tak mahu komplen. Ada hubungan dengan agensi luar. (Because there is a weakness from the family's side to monitor. There must be a role but there should be no complaints. And there must be networks with external agencies)."

The third theme is the format of the report (Respondents 4 and 7). Respondent 4 said, "Pertama sekali, masih perlu tambah dalam laporan akhlak contohnya salah kecil campur salah besar. Lepas tu terlalu ringkas. Ada elemen yang tak cukup seperti gambar. (Firstly, there is a need to improve the report, for example minor offences are mixed with major ones. And it is too short. There are missing elements such as photos)." Meanwhile, Respondent 7 said, "Penyediaan laporan perlu ditambah. Format sekarang terlalu simple. Juga isu masa yang boleh menyebabkan laporan tak berkualiti. (The preparation of the report needs to be added. The current format is too simple. There is also an issue of time that may contribute to low-quality reports)."

\section{Question 2: The Rehabilitation of the Child Offenders by the Institution's Offered Programmes}

The scores given for this item were also above average $(\mu=3.83)$. The most frequent score given was $4(n=6)$. Responses on this item were sometimes tangential; for the qualitative portion, the first two themes (offenders' will to change and availability of support) do not relate to the effectiveness of the institution despite the nature of the question. The third and fourth theme, however, related to ways the design of the institution could hinder effective participation in the process.

The first theme identified is the offenders' own will to change. Respondent 3 maintained his positive perspective regarding the services and said, "Sebab bagi saya perkhidmatan ni sudah cukup berkesan. Tapi kalau tak berubah tu sebab diri dia sendirilah. (Because to me the services provided are very effective. If they do not change, it is their own doing)." Respondent 10 elaborated, "Sebab bergantung pada diri. Tempoh asrama setahun je. Bergantung juga kepada petugas kat dalam. Dan kena ada program khusus kanak-kanak. (Because it depends on oneself. The detention period is only a year. It also depends on the internal officers-in- 
charge. And there should also be special programmes for children)." Meanwhile, Respondent 12 explained why the offenders might not change, stating, "Contohnya dia kesalahan kecil tapi bercampur dan tak nampak lagi yang keluar berjaya. (For example, he committed a minor offence but he developed a close association with major offenders, and I haven't see those who have been successful in life after leaving the detention centre)."

The second theme relates to the support available for released offenders, especially from their families (Respondents 2, 5, and 6). Respondent 2 said, "Sebab diorang kan terpengaruh kat luar. Masuk lepas tu insaf kat dalam tapi bila kat luar hilang sokongan balik. (Because they were influenced by external elements. They get in, change, and then when they leave, they lose the support)." Respondents 5 and 6 emphasised support from the family. Respondent 5 said, "Sebab apa yang diajar dekat asrama tak kekal kat luar. Sebab keluarga tak jaga. (Because what is taught in the detention centres is not maintained outside. It's because the family neglects them)." Respondent 6 added, "Agama, sekolah kemahiran cukup semua, tapi bergantung kepada budak-budak untuk berubah. Dan pemantauan dari keluarga tak ada. (There are sufficient religious and development skill classes but it all depends on the children to change. And what is lacking is close monitoring from the family)."

Respondents 1, 4, 7, 9, and 10 pointed out the short period of the offenders' detention inside the institution. Respondent 1 said, "Bagi saya tempoh singkat. Tak cukup untuk modul pendidikan. (For me, the time is too short. It is not enough for educational modules)." Respondent 4 added, "Sebab pengisian dalam $n i$ longgar macam pengisian spiritual, lepas tu 12 bulan tu macam sementara je. Dan asingkan mereka pun tak bagus juga. (Because the modules in here are not that effective like the spiritual modules, and the 12 months are too short. And it is also not good to isolate them)." Respondent 7's response was similar to Respondents 1 and 4's elaboration on the modules. Respondent 9 added another point, "Sebab tempoh terlalu singkat. Lepas tu program kurang kakitangan. (Because the time is too short. And then there is a shortage of staff to implement the programme)."

The final theme under this section is the need for effective modules (Respondents 1, 4, 7, 8, 10, and 11). Respondent 8 said, "Modul tak lengkap, ikut asrama tu, tak tetap. Ada juga masalah lain macam masalah staf, bantuan dan peruntukan. (The modules are not complete, it depends on the hostel, and they are also inconsistent. There are also other problems such as staff problems, assistance, and [funding] allocation)." Respondent 11 said, "Cara pengurusan yang sama di seluruh asrama. Tiada pendekatan kemahiran, contoh tak pergi sekolah. Kena ada kursus, kena ada aktiviti dan program. (The management style should be the same across centres. There are no skills modules, like for some who do not go to school, there must be modules, activities and programmes)." 


\section{Question 3: The Outcomes of the Juvenile Offenders Being Housed Inside the Institution}

This is the first question that prompted a below average score from any respondent. The mean of the scores is 3.0. The most frequent score given is $3(n=9)$. The lower rating may be because this question did not ask directly about the institutions at which they are employed, possibly allowing respondents to feel more comfortable in being critical. Supporting this view, quantitative scores on this question more closely matched the ambivalences expressed by the qualitative themes.

On the qualitative section, respondents made various points regarding the child offenders' capacity to desist from committing crime upon release. Respondent 4 emphasised on the various interplaying factors that influence desistance and said, "Kena tengok juga banyak faktor dia. Macam contohnya, diorang masuk tu sebab apa? Tabiat diorang macam mana? Penolakan dari keluarga? Jenayah seksual? (We need to look at many factors. For example, why did they enter here? What kind of habits have they acquired? Rejection from family? Sexual crime?)." The rest of the responses are listed according to the following themes:

1. Support outside detention: Respondents 5, 6, 8, and 11 pointed out the importance of an offender's support structure outside detention. Responses from Respondents 6 and 8 were general. Respondent 6 said, "Sebab tak ada satu sistem pemantauan kat luar. Macam, jangan diberikan kebebasan total lepas keluar tapi terus untuk diberikan kemahiran. (Because there is no monitoring system outside. For example, we should not give total freedom outside but must keep on training them)." Respondent 8 said, "Dia ikut panduan yang diberikan. Kalau dia keluar, tapi tak didorong mungkin boleh terjebak. (He must follow the guidelines given. If he is released, but not guided, then he may be involved [again in crime])." Respondents 5 and 11 emphasised the role of the family. Respondent 5 explained why she said the desistance might not last long, "Sebab keluarga tak memainkan peranan penting. (Because the family does not play an important role)."

2. Peer influence: Respondent 7 believes that relapse cases are often due to peers, stating: "Banyak kes berulang-ulang. Mungkin dia belajar dari kawan-kawan dia yang kat dalam tu. (A lot of repeat cases. Maybe he learns from his friends inside the detention centre)." Respondent 12 said, "Tak yakin sebab keluar nanti dengan kawan boleh jadi balik. (I am not so confident because when they are out, they will be with their friends and they might reoffend)." 
3. Self-efficacy: Respondents 2 and 3 commented on the offenders' own willingness to change. Respondent 2 said, "Sebab diri diorang yang tak kuat. Dia yang kena berubah. (Because they are not strong themselves. They have to change)." Respondent 3 maintained his previous answer, elaborating, "Sebab benda ni bergantung kepada diri sendiri. Kalau dia kuat dia akan berubah. (Because this depends on the self. If he is strong, he will change)."

4. Short period of detention: Respondent 1 said, "Tempohnya yang tak cukup untuk menyediakan diri kanak-kanak tu. (The time is not enough to prepare the children)." Respondent 9 also repeated the same point.

\section{Question 4: The Probation Officers' Feedback for New Initiatives That Might Help in Improving the Rehabilitation of Offenders}

For this item, the respondents were solicited for suggestions of any programmes that could be offered to incarcerated juveniles. Respondents 1, 5, and 12 simply said "don't know" or "haven't thought of it." Meanwhile, Respondent 6 deferred, responding, "Saya rasa soalan ni lagi sesuai tanya warden asrama akhlak tu, sebab dia yang duduk dengan juvana ni hari hari. (I think it's better to enquire from the warden of the [detention] centre, because he is the one who stays with the juveniles everyday)." Respondent 3 suggested, "Bagi saya, program untuk pastikan dia tak terlibat lagi dengan jenayah ni. (For me, programmes to ensure that these [child offenders] will not be involved in crimes again)."

Respondents 2, 4, 6, and 9 suggested family-related programmes and programmes that would motivate offenders to maintain desistance. Respondent 2 said, "Program kemahiran keibu-bapaan. Untuk penerimaan bila pesalah ni dah keluar. Dan bengkel motivasi untuk menyediakan diri dekat luar. (Programme on parenting skills. This is for them to be accepted by society when the offenders are released. And also motivational modules to prepare them for the outside world)." Respondent 4 added, "Program tak menyerlah lepas tu program ada tapi tak aktif. Cuba jadikan anak angkat atau jadikan pekerja. Lagipun perlu ada sumber motivasi dari luar. (The programmes [as of now] were not outstanding. There are programmes but they are not implemented as planned. Try to organise child adoption or hire them for a job. Furthermore, there should be a source of motivation from outside)."

The responses of Respondents 7, 8, 9, and 10 endorsed modules that sharpen various skills. Respondent 7 said, "Kemahiran kena ada. Partnership dengan agensi lain pun bagus. (They must acquire skills. Partnership with other agencies is also good)." Respondent 8 said, "Kemahiran yang boleh membantu diorang berdikari. (Skills that can make them independent)." Respondent 9 added, 
"Bagi saya program latihan kemahiran. Sebab kalau ada pun tak tetap. Lepas tu program interaksi antara kanak-kanak dan keluarga. (For me, skills modules. Because even if there are any, they are inconsistent. And these include programmes that encourage interaction between the children and their respective families)." Respondent 10 simply said, "Kena ada kursus panjanglah. (There must be longterm modules)."

\section{DISCUSSION}

Probation officers were chosen as the respondents for this study based on the importance of their relationship with offenders and its influence on the efficacy of offender rehabilitation (Burnett and McNeill, 2005; Paparozzi and Gendreau, 2005). In Malaysia, probation officers dealing with juvenile offenders are the welfare officers assigned to the Child Unit in the Social Welfare Department of Malaysia. Probation officers play a significant role in the sentencing aspects of a juvenile offender, which includes interviewing the offenders and preparing a probation report. Therefore, this study agrees with the argument that their perception of the efficacy of the juvenile justice - as operationalised to three key elements by Mutter et al. (2008) - should be integral to the assessment of whether the system works effectively.

The first most notable observation from the responses is the role of time in their evaluations. From the responses, there are two aspects of the processes where the concept of time is central. The two aspects are the time required for the probation officers to write up a probation report, and the duration of time for which juvenile offenders are required to reside in the rehabilitative institutions. Several respondents pointed out the insufficient time available for them to write a comprehensive and high-quality report, which may affect the assessment. This affirms the arguments of several academics, who have expressed concern about the speed at which probation officers are expected to produce work output and the impact on the quality of their work (Davies and Gregory, 2010; Nellis, 2002).

The implicit pressure to achieve targets has been noted by Annison, Eadie, and Knight (2008), who observed that while probation officers gained satisfaction from having connection with people, they were often frustrated with the shortage of time available to do their job. Their frustration is reasonable, as probation officers are expected to deliver impartial and accurate assessment reports to the decision makers in the juvenile justice system (House of Commons Justice Committee, 2011; The Child Justice Alliance, n.d.). This goal of generating assessment reports that reflect the psychosocial aspects of the juvenile offenders accurately may be compromised by the limited time available to prepare reports. This issue warrants additional examination. 
Also relating to time, respondents in this study remarked frequently on the duration of institutionalisation. However, this is at tension with some research, such as a meta-analysis conducted by Smith, Goggin, and Gendreau (2002), which observed from past studies that the duration of incarceration did not affect the rate of recidivism. This study agreed with what was argued by Smith, Goggin, and Gendreau (2002) as recidivism rate may be influenced not by the length of detention or incarceration, although the probation officers may have a contrasting point of view about how long the offenders should be rehabilitated. Instead, what may be more important is the type of intervention or measures conducted post-conviction (Lipsey and Cullen, 2007). Programmes based on the approach of restorative justice, for example, are shorter in duration but shown to be effective against recidivism (e.g. Bradshaw and Roseborough, 2005; Bradshaw, Roseborough and Umbreit, 2006).

The answers to the open-ended question relating to programme modules also touched on the theme of limited time and resources. The probation officers' suggestions regarding the need to educate the juvenile offenders on certain skills dovetail with what previous studies have found to be an effective element in the rehabilitation juvenile offenders. In regard to teaching modules, some scholars differentiate between different skills that can be taught to the offenders (Mackenzie, 2009, quoted in Gillies et al., 2014). Agreeing with the importance of education given to offenders, Gillies et al. (2014) emphasised the negative correlation found between education and recidivism. This decline in recidivism may be due to education allowing offenders to become recognised as valuable members of the community.

However, Mackenzie (2009, as cited in Gillies et al., 2014) noted that life skills that train the offenders various aspects of life did not affect the rate of recidivism. Studies have shown that a large proportion of the incarcerated juvenile offenders have at least one psychiatric disorder (Thielbar, n.d.; Rosenblatt, Rosenblatt and Biggs, 2000). This is also observed among the Malaysian juvenile offenders (Aida et al., 2014). Rosenblatt, Rosenblatt and Biggs (2000) further argued that the prevalence of psychiatric disorders among the juvenile offenders leads some to believe that juvenile offenders may not respond to treatment (or educational measures) as well as other adolescents. This adds an additional layer to the module-related comments offered by the respondents. The kind of modules to which "normal" adolescents may respond (such as the modules related to life skills) may not have the same effect on the juvenile offender population. Further research into skills-enhancing modules tailored to this population is warranted.

The probation officers in this study have also placed great emphasis on the support given to juvenile offenders upon release. Among the keypoints highlighted was that recidivism often occurred because of insufficient social support upon release, especially from family. Previous research has discovered that offenders 
themselves expect family support upon release (Naser and La Vigne, 2006). This is consistent with studies that indicate the importance of a healthy relationship between juvenile offenders and their families, which can affect their desistance after release (Austin and Hardyman, 2004; Mowen and Visher, 2015; Rosansky, 2010).

\section{THE DISCREPANCY BETWEEN THE QUANTITATIVE AND QUALITATIVE DATA}

For all items (especially for Items 1 and 2, and to a lesser extent in Item 3), the ratings given by the respondents were somewhat inconsistent with the qualitative reports that asked them to explain their ratings. Item 1, for example, asked the respondents to rate their perception (whether positive or negative) of the processes of preparing child offenders for institutions. The mean of the rating was higher than average, indicating a more positive perception towards the item asked. However, when asked to elaborate, respondents more often provided negative responses.

To address the discrepancy between findings that incorporate both the quantitative and qualitative approach, Moffatt et al. (2006) suggested six ways: (1) treating the methods as fundamentally different; (2) exploring the methodological rigour of each component; (3) exploring dataset comparability; (4) collecting further data and making further comparisons; (5) exploring the process of the intervention; and (6) exploring whether the outcomes of the two components match. Methodologically, this study acknowledges that the low sample size may result in the findings not being able to identify even the smallest difference, which is one limitation of this study.

Embracing the final suggestion by Moffatt et al. (2006), we would like to explore the matchability of the findings of both quantitative and qualitative components. To do this, it is helpful to consider two system models as reported by Hazel (2008), namely the welfare and justice models. The welfare model is influenced by the idea of child protection; hence the goal is mainly treatment, rather than punishment. On the other hand, the justice model emphasises the responsibilities of individuals where the roles of the law to punish those who deserve it should be upheld. Malaysia adopts a punitive system (Nasimah, 2010) that fits the less-flexible justice model of systems. Probation officers may hold conflicting philosophies in their work (Harris, 1980). In a justice model system such as Malaysia, probation officers may be expected to uphold the law and avoid flexibility, but contradictorily, they may also hold points of view where the systems should function to rehabilitate the offenders.

Therefore, these different philosophies that may clash may influence the matchability of the outcomes from the quantitative and qualitative parts of the 
current study. To address this, Moffatt and colleagues' first suggestion to treat the two methods as fundamentally different may be of value. They asserted that "[c]ombining the two methods for crossvalidation (triangulation) purposes is not a viable option because it rests on the premise that both methods are examining the same research problem" (Moffatt et al., 2006: 6). Therefore, the different philosophies may represent different research problems that should be treated differently. This serves as a suggestion for future research where the internally conflictive philosophies of the probation officers should be taken into consideration in data collection and interpretation.

\section{FRAMEWORK OF IMPROVED PARTICIPATION OF JUVENILE OFFENDERS IN THE JUVENILE JUSTICE}

Based on the responses of the probation officers participating in the current study, we briefly propose a framework of the improved participation of juvenile offenders in the juvenile justice system. The framework is presented in respect to three layers of participation: (1) The process of preparation; (2) The detention itself, and; (3) The release from detention.

In the first layer of participation, the process of preparation, we emphasise both the role of assessment preparation and the network between agencies. In respect to assessment preparation, the probation officers highlighted the importance of extending the time period in which the asssment is prepared, allowing for a more comprehensive and accurate report. Also instrumental at this layer is the effect (and efficacy) of the network between agencies. This factor is important, given that the juvenile offenders' experiences are shaped by different authorities, including not only the probation officers, but also police, court personnel and others.

For the second layer, which is the detention proper, the probation officers focused on two primary factors: the duration of the detention, and the availability of modules. Although earlier on this article did not wholly agree with the requirement of a longer detention, it still echoes the point of the duration itself, where different durations may suit different programmes of rehabilitation. In respect to modules, we note the emphasis of respondents on the acquisition of skills, but also the crucial need to tailor modules to the needs of incarcerated juveniles.

For the third layer, which is the release phase, the probation officers focused on the elements of support and the availability of post-release modules. Although some respondents mentioned the word "support" in a general sense, many specifically emphasised family support. Although modules were also endorsed as part of the second layer of this framework, we also note that post-release modules focus on strengthening the family institution to enhance the family support. 
The framework is presented in Figure 1.

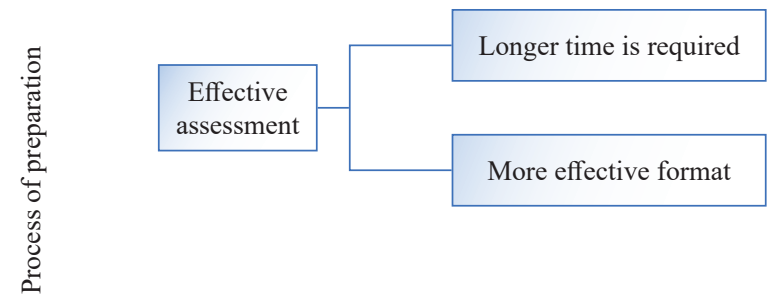

Better network with other agencies

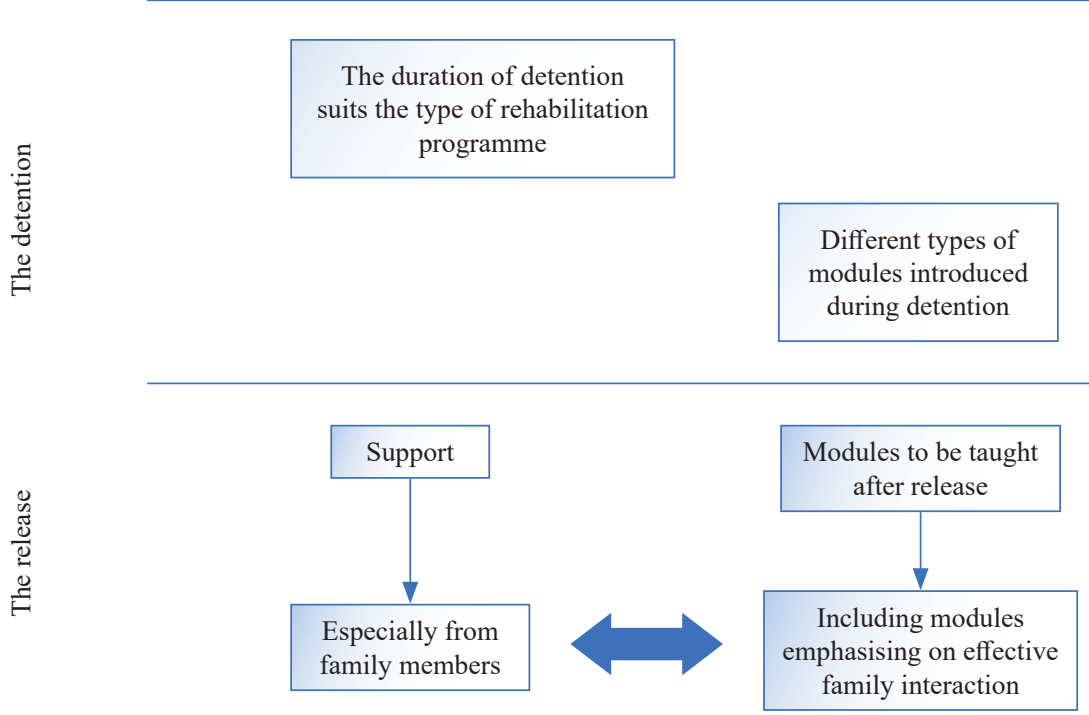

Figure 1: Framework of an improved participation of juvenile offenders in the system.

\section{CONCLUSION}

Probation officers are among the authorities closest to the experiences of juvenile offenders in the justice system. Hence, they are also among the individuals whose feedback and perception of the current system would be pivotal, since they are "first responders" within the juvenile justice system. Through this view, this study interviewed several probation officers on their perceptions and opinions of the experience of juvenile offenders in the juvenile justice system. The aspects of participation include the process of preparation for detention, the detention itself, and the process of release. 
Many of the observed responses reflected on the role of the juvenile offenders themselves. This included respondents' emphasis on the willingness of offenders to change. In addition to this, the probation officers said that the external sources of support - mainly the juvenile offenders' family members - are pivotal. Institutional variables and the elements of time - both in terms of incarceration duration and the evaluative process - were frequently highlighted. Also emphasised were the modules introduced during and after detention, based on their role in equipping the juvenile offenders with critical skills.

The views of the probation officers shed light on how the current process of participation can be improved for the betterment of juvenile offenders. The framework created based on the responses can be used to facilitate policy making related to juvenile justice and the incarceration of juvenile offenders. While further research into the details of implementation is warranted, we believe that this framework - informed by the experiences and perspectives of "first responders" can help inform improvements to the juvenile justice system.

\section{ACKNOWLEDGEMENTS}

This research was funded by a Top Down research grant by Universiti Sains Malaysia. Special thanks to the participants for their dedicated time and commitment in the mediation sessions.

\section{REFERENCES}

Aida, S. A., H. H. Aili, K. S. Manveen, W. I. Salwina, K. P. Subash, C. G. Ng and A. G. Muhsin. 2014. Prevalence of psychiatric disorders among juvenile offenders in Malaysian prisons and association with socio-demographic and personal factors. International Journal of Prisoner Health 10: 132-143. https://doi.org/10.1108/ IJPH-06-2013-0029

Annison, J., T. Eadie and C. Knight. 2008. People first: Probation officer perspectives on probation work. Probation Journal: The Journal of Community and Criminal Justice 55(3): 259-271. https://doi.org/10.1177/0264550508095122

Austin, J. and P. L. Hardyman. 2004. The risks and needs of the returning prisoner population. Review of Policy Research 21: 13-29. https://doi.org/10.1111/j.15411338.2004.00055.x

Bradshaw, W., D. Roseborough and M. S. Umbreit. 2006. The effect of victim offender mediation on juvenile offender recidivism: A meta-analysis. Conflict Resolution Quarterly 24: 87-98. https://doi.org/10.1002/crq.159

Bradshaw, W. and D. Roseborough. 2005. Restorative justice dialogue: The impact of mediation and conferencing on juvenile recidivism. Federal Probation 69: 15-21. 
Braun, V. and V. Clarke. 2006. Using thematic analysis in psychology. Qualitative Research in Psychology 3: 77-101. https://doi.org/10.1191/1478088706qp063oa

Burnett, R. and F. McNeill. 2005. The place of the officer-offender relationship in assisting offenders to desist from crime. The Journal of Community and Criminal Justice 52: 221-242. https://doi.org/10.1177/0264550505055112

Chung, H. L. and L. Steinberg. 2006. Relations between neighborhood factors, parenting behaviors, peer deviance, and delinquency among serious juvenile offenders. Developmental Psychology 42: 319-331. https://doi.org/10.1037/00121649.42.2.319

Davies, K. and M. J. Gregory. 2010. The price of targets: Audit and evaluation in probation practice. Probation Journal 54: 400-414. https://doi. org/10.1177/0264550510381327

Dorey, P. 2005. Policy making in Britain: An introduction. Newcastle: SAGE. https://doi. org/10.4135/9781446279410

Galbavy, R. J. 2003. Juvenile delinquency: Peer influences, gender differences, and prevention. Journal of Prevention \& Intervention in the Community 25: 65-78. https://doi.org/10.1300/J005v25n02_05

Gillies, R., A. Carroll, K. Swabey, D. Pullen, A. Fluck and J. Yu. 2014. The role of postsecondary education among ex-inmates living crime-free. Proceedings of the 2014 joint Australian Association for research in education and New Zealand Association for research in education conference, Brisbane, Australia. 30 November-4 December.

Harris, R. J. 1980. A changing service: The case for separating 'care' and 'control' in probation practice. British Journal of Social Work 10: 163-184.

Hazel, N. 2008. Cross-national comparison of youth justice. London: Youth Justice Board for England and Wales.

Heslop, J. 1991. Diverting young offenders from the formal justice system. In Preventing juvenile crime conference proceedings, no. 9, eds. J. Vernon and S. McKillop, 81-87. Canberra: Australian Institute of Criminology.

House of Commons Justice Committee. 2011. The role of the probation service. London: House of Commons. http://www.publications.parliament.uk/pa/cm201012/ cmselect/cmjust/519/519i.pdf.

Jaafar Abdul Wahid. 1978. The treatment of juvenile delinquents and youthful offenders in Malaysia. Japan: United Nations Asia and Far East Institute. https://www.ncjrs. gov/pdffiles1/Digitization/51521NCJRS.pdf.

Lipsey, M. W. and F. T. Cullen. 2007. The effectiveness of correctional rehabilitation: A review of systematic reviews. Annual Review of Law and Social Science 3: 297-320. https://doi.org/10.1146/annurev.lawsocsci.3.081806.112833

Lipsey, M. W., D. B. Wilson and L. Cothern. 2000. Effective intervention for serious juvenile offenders. Juvenile Justice Bulletin. April. https://www.ncjrs.gov/ pdffiles1/ojjdp/181201.pdf.

McLaughlin, E. and J. Muncie, eds. 2013. Abolition. The SAGE dictionary of criminology. London: SAGE Publications Ltd. 
Ministry of Women, Family and Community Development and UNICEF Malaysia. 2013. The Malaysian juvenile justice system: A study of mechanisms for handling children in conflict with the law. Putrajaya: Ministry of Women, Family and Community Development.

Moffatt, S., M. White, J. Mackintosh and D. Howel. 2006. Using quantitative and qualitative data in health services research - what happens when mixed method findings conflict? BMC Health Services Research 6: 28. https://doi. org/10.1186/1472-6963-6-28

Mohd Al Adib Samuri and Nooraziah Mohd Awal. 2009. Hukuman terhadap pesalah kanak-kanak di Malaysia: Pencegahan atau pemulihan? Jurnal Undang-Undang $35-54$.

Mowen, T. J. and C. A. Visher. 2015. Drug use and crime after incarceration: The role of family support and family conflict. Justice Quarterly 32: 337-359. https://doi.org /10.1080/07418825.2013.771207

Mutter, R., D. Shemmings, P. Dugmore and M. Hyare. 2008. Family group conferences in youth justice. Health and Social Care in the Community 16: 262-270. https://doi. org/10.1111/j.1365-2524.2008.00770.x

Naser, R. L. and N. G. La Vigne. 2006. Family support in the prisoner reentry process. Journal of Offender Rehabilitation 43: 93-106. https://doi.org/10.1300/ J076v43n01 05

Nasimah Hussin. 2010. The rights of victims of crime under Malaysian law: Legal framework and prospect for reforms. The International Journal of Interdisciplinary Social Sciences 5: 35-43. https://doi.org/10.18848/1833-1882/CGP/v05i04/51661

Nellis, M. 2002. Community justice, time and the new national probation service. Howard Journal of Criminal Justice 41: 59-86. https://doi.org/10.1111/1468-2311.00225

Paparozzi, M. A. and P. Gendreau. 2005. An intensive supervision program that worked: Service delivery, professional orientation, and organizational supportiveness. The Prison Journal 85: 445-466. https://doi.org/10.1177/0032885505281529

Rosansky, J. 2010. Reducing recidivism: Stopping the trend of criminal relapse in America. https://www.palmbeachstate.edu/academicservices/Documents/Reducing_ Recidivism.pdf

Rosenblatt, J. A., A. Rosenblatt and E. E. Biggs. 2000. Criminal behavior and emotional disorder: Comparing youth served by the mental health and juvenile justice systems. Journal of Behavioral Health Services \& Research 27: 227-237. https://doi.org/10.1007/BF02287315

Siegel, L. J. and B. C. Welsh. 2016. Juvenile delinquency: The core. Boston: Cengage Learning.

Smith, P., C. Goggin and P. Gendreau. 2002. The effects of prison sentences and intermediate sanctions on recidivism: General effects and individual differences. Ottawa: Solicitor General Canada.

Suruhanjaya Hak Asasi Manusia Malaysia (SUHAKAM). 2008. Human rights and the administration of juvenile justice. Malaysia: SUHAKAM. http://www. iccwtnispcanarc.org/upload/pdf/7965505086Human\%20Rights\%20and\%20 the\%20Administration\%20of\%20Juvenile\%20Justice.pdf. 
The Child Justice Alliance. n.d. What is the role of probation officers? The Child Justice Alliance. http://www.childjustice.org.za/downloads/FactSheets/What $\% 20$ is $\% 20$ the $\% 20$ role $\% 20$ of $\% 20$ probation $\% 20$ officers-revised.pdf.

Thielbar, K. n.d. Education in juvenile detention centers. Chicago, IL: Loyola University Chicago. http://www.luc.edu/media/lucedu/law/centers/childlaw/childed/pdfs/ 2011studentpapers/thielbar_juvenile_detention.pdf.

Wemmers, J. 2009. Where do they belong? Giving victims a place in the criminal justice process. Criminal Law Forum 20: 395-416. https://doi.org/10.1007/s10609-0099107-z

Worrall, A. and R. C. Mawby. 2014. Probation worker cultures and relationships with offenders. Probation Journal 61: 346-357. https://doi.org/10.1177/ 0264550514548251 